\title{
Peningkatan Hasil Belajar Matematika tentang Nilai dan Kesetraan Pecahan Mata Uang Melalui Media Video Pembelajaran Pada Siswa Sekolah Dasar
}

\author{
Mutik Ati Masrifatun \\ SDN 1 Dukun \\ mutikatimasrifatun@gmail.com
}

\section{Article History}

accepted 01/11/2020

approved 08/11/2020

published 15/11/2020

\begin{abstract}
This research is an effort to improve Mathematics learning outcomes about the value and equivalence of currency fractions in grade II SD Negeri Dukun 1. Classroom action research was carried out through 2 cycles, namely cycle I and cycle II. Each cycle contains planning, implementation, observation and reflection. The data collection methods used include observation, tests, and documentation. Data analysis was carried out by calculating the achievement of the learning outcomes in each cycle marked by an increase in Classical Completeness Criteria. The results obtained in this study were that there was an increase in student learning outcomes for Mathematics about the value and equivalence of currency denominations in class II SD Negeri Dukun 1 students. students who complete learning, in cycle I increased to $50 \%$, increased in cycle II to $90 \%$ of students completed. Based on these learning outcomes, it can be concluded that through the media of instructional videos it can improve Mathematics learning outcomes about the value and equivalence of currency fractions in grade II SD Negeri Dukun 1 st.
\end{abstract}

Keywords: Learning Outcomes, Learning video media

\begin{abstract}
Abstrak
Penelitian ini bertujuan untuk meningkatkan hasil belajar Matematika tentang nilai dan kesetaraan pecahan mata uang pada siswa kelas II SD Negeri Dukun 1. Penelitian tindakan kelas dilaksanakan melaui 2 siklus yaitu siklus I dan siklus II. Tiap siklus masing-masing terdapat perencanaan, pelaksanaan, pengamatan dan refleksi. Adapun metode pengumpulan data yang digunakan meliputi observasi, tes, dan dokumentasi. Analisis data yang dilakukan dengan cara menghitung pencapaian nilai hasil belajar tiap siklus dengan ditandai peningkatan Kriteria Ketuntasan Klasikal. Hasil yang diperoleh dalam penelitian ini adalah terjadi peningkatan hasil belajar siswa untuk mata pelajaran Matematika tentang nilai dan kesetaraan pecahan mata uang pada siswa kelas II SD Negeri Dukun 1. Melalui media video pembelajaran ada peningkatan hasil belajar, hal ini dapat dilihat kondisi awal yaitu $30 \%$ siswa yang tuntas belajar, pada siklus I meningkat menjadi 50\%, meningkat pada siklus II menjadi $90 \%$ siswa tuntas. Berdasarkan hasil belajar tersebut dapat disimpulkan bahwa melalui media video pembelajaran dapat meningkatkan hasil belajar Matematika tentang nilai dan kesetaran pecahan mata uang pada siswa kelas II SD Negeri Dukun 1.
\end{abstract}

Kata kunci: Hasil Belajar, Media video Pembelajaran

Social, Humanities, and Education Studies (SHEs): Conference Series https://jurnal.uns.ac.id/shes

p-ISSN 2620-9284

e-ISSN 2620-9292 


\section{PENDAHULUAN}

Pembelajaran jarak jauh atau daring ini dimulai pada tanggal 19 maret 2020, dimana anak mulai belajar dari rumahnya masing-masing tanpa perlu pergi kesekolah. Berbicara mengenai pembelajaran jarak jauh atau daring maka pentingnya penguasaan ilmu teknologi bagi seorang guru agar pembelajaran jarak jauh tetap berjalan dengan efektf disaat pandemi seperti ini. Guru harus melakukan inovasi dalam pembelajaran diantaranya dengan memanfaatkan teknologi dalam pembelajaran. Semenjak pembelajaran diberlakukan dirumah, sebagian guru melakukan pembelajaran lewat media online seperti Whatsapp, zoom, google form, dll.

Dari hasil evaluasi pada pembelajaran daring Matematika tentang menjelaskan nilai dan kesetraan pecahan mata uang diperoleh hasil bahwa rata- rata nilai siswa masih dibawah KKM. Memperhatikan permasalahan tersebut penulis mengadakan diskusi dengan teman sejawat dan konsultasi dengan sepervisor, akhirnya penulis mendapatkan masukan, arahan maupun saran. Dari hasil diskusi tersebut terdapat beberapa masalah yang terjadi dalam proses kegiatan pembelajaran antara lain :Kesulitan dalam pembelajaran daring pembelajaran kurang efektif, Perhatian siswa masih kurang fokus pada pelajaran, Kesulitan memberi contoh yang lebih bersifat konkret terutama dalam materi Matematika tentang menjelaskan nilai pecahan mata uang, Penggunaan alat peraga yang kurang menarik, Interaksi antara siswa dan guru, siswa dengan siswa, masih kurang, dan Pemilihan media yang kurang tepat.

Oleh karena itu peneliti mencoba merumuskan Masalah sebagai berikut: "Bagaimana penggunaan media video pembelajaran dapat meningkatkan hasil belajar Matematika tentang nilai dan kesetaraan pecahan mata uang pada siswa kelas II SDN Dukun 1?"

Belajar menurut W.S. Winkel adalah suatu aktivitas mental atau psikis yang berlangsung dan interaksi aktif dengan lingkungan, yang menghasilkan perubahan dalam pengetahuan - pemahaman, ketrampilan, dan nilai sikap. berdasarkan pengertian belajar dari banyak ahli pendidikan tersebut, dapat ditarik kesimpulan bahwa pengertian belajar secara umum adalah suatu kegiatan yang mengakibatkan terjadinya perubahan tingkah laku (Darsono, dkk, 2000: 24). Sedangkan pengertian hasil belajar adalah kemampuan yang dimiliki siswa setelah ia manerima pengalaman belajarnya. Kingsley (Sudjana, 2001:22) membagi tiga macam pengertian; tiga sikap dan cita-cita yang masing-masing golongan dapat diisi dengan bahan yang ada pada kurikulum sekolah. Menurut Kamus Besar Bahasa Indonesia, video merupakan rekaman gambar hidup atau program televisi untuk ditayangkan lewat pesawat televisi, atau dengan kata lain video merupakan tayangan gambar bergerak yang disertai engan suara. Video sebenarnya berasal dari bahasa Latin, video-vidivisum ng artinya melihat (mempunyai daya penglihatan); dapat melihat. Media video merupakan salah satu jenis media audio visual. Media audio visual adalah media yang mengandalkan indera pendengaran dan indera penglihatan. Media audio visual merupakan salah satu media yang dapat digunakan dalam mbelajaran menyimak. Media ini dapat menambah minat siswa dalam belajar karena siswa dapat menyimak sekaligus melihat gambar. Azhar Arsyad (2011 : 49) menyatakan bahwa video merupakan gambargambar dalam frame, di mana frame demi frame diproyeksikan melalui lensa proyektor secara mekanis sehingga pada layar terlihat gambar hidup. Dari pengertian di atas dapat disimpulkan, bahwa video merupakan salah satu jenis media audio-visual yang apat menggambarkan suatu objek yang bergerak bersama-sama dengan suara alamiah atau suara yang sesuai.

Adapun tujuan Penelitian ini adalah untuk meningkatkan hasil belajar matematika tentang nilai dan kesetaraan pecahan uang melalui media video pembelajaran pada siswa kelas II SD Negeri Dukun 1. 


\section{METODE}

Jenis penelitian ini adalah Penelitian Tindakan Kelas (PTK). Penelitian Tindakan Kelas (PTK) adalah penelitian yang dilakukan oleh guru di dalam kelasnya sendiri melalu refleksi diri, dengan tujuan untuk memperbaiki kinerjanya sebagai guru, sehingga proses pembelajaran dapat berjalan dengan baik dan hasil belajar siswa meningkat (Hamzah B. Uno dkk, 2011: 41). Sementara menurut Wina Sanjaya (2011: 26) PTK diartikan sebagai proses pengkajian masalah pembelajaran di dalam kelas melalui refleksi diri dalam upaya untuk memecahkan masalah tersebut dengan melakukan berbagai tindakan yang terencana dalam situasi nyata serta menganalisis setiap pengaruh dari perlakuan tersebut.

Data atau informasi yang paling penting untuk dikumpulkan dan dikaji dalam penelitian ini diperoleh dari : 1. data kualitatif, diperoleh dari informasi tentang seberapa besar perubahan pembelajaran ketika guru mengajar matematika menggunakan media video pembelajaran pada siswa kelas II SDN Dukun 1, 2. data kuantitatif, diperoleh dari hasil belajar siswa yaitu berupa hasil tes untuk mengetahui kemampuan siswa dan kondisi pembelajaran yang dilakukan sebelum adanya tindakan penelitian.

Adapun sumber data dalam penelitian ini yaitu: 1. Siswa, 2. Guru, 3. Observer , dan 4. Dokumen.

Teknik pengumpulan data yang digunakan penelitian tindakan kelas ini adalah tes, observasi dan dokumentasi sementara untuk bentuk instrumen yang digunakan dalam penelitian ini adalah Soal Tertulis dan Lembar Observasi.

Teknik analisis data yang digunakan dalam penelitian ini adalah teknik analisis data deskriptif kualitatif. Yaitu menarik kesimpulan data-data yang diperoleh pada kondisi awal, siklus 1, dan siklus II yang berupa data kualitatif maupun data dari observasi yang dilakukan oleh pengamat/ kolabolator, dengan tahapan a. Tahap pengumpulan data, b. Tahap reduksi data, c. Tahap penyajian data, d. Tahap penarikan kesimpulan. Untuk Hasil tes dianalisis secara deskriptif kuantitatif untuk mengetahui seberapa besar peningkatan hasil belajar kognitif matematika materi menjelaskan nilai dan kesetaraan pecahan mata uang melalui media video pembelajaran. Data hasil tes yang diperoleh pada akhir siklus dihitung rata-rata kelasnya dan dihitung persentase siswa yang tuntas.

\section{HASIL DAN PEMBAHASAN}

Pada awalnya peneliti merenungkan hasil nilai siswa pada muatan mata pelajaran matematika tentang menentukan nilai dan kesetaraan pecahan mata uang menunjukan angka yang paling rendah dibandingkan dengan muatan mata pelajaran lainnya. Dari hasil penilaian sebelum melakukan tindakan pertama (siklus pertama), dikatahui kondisi awal prestasi belajar siswa. Hasil prestasi kondisi awal dapat dilihat dari data dibawah ini : 
Tabel 1 Hasil belajar siswa pada kondisi awal Kondisi Awal

\begin{tabular}{|l|l|}
\hline & Kondisi awal \\
\hline Nilai tertinggi & 80 \\
\hline Nilai terendah & 20 \\
\hline Rata - rata Nilai & 65 \\
\hline Siswa belajar Tuntas & $30 \%$ \\
\hline Siswa belajar Belum Tuntas & $70 \%$ \\
\hline
\end{tabular}

Dari tabel di atas dapat dilihat bahwa nilai terendah yang diperoleh siswa adalah 20 , nilai tertinggi adalah 80 , dan rata-rata nilainya 65 , serta siswa yang telah belajar tuntas baru $30 \%$, maka masih banyak siswa yang belum mencapai nilai ketuntasan $(\mathrm{KKM}=75)$. Sehinga perlu diadakan tindakan untuk meningkatkan hasil belajar matematika pada umumnya, dan pada materi menentukan nilai dan kesetaraan pecahan mata uang pada khususnya.

Deskripsi Penelitian Siklus I

Data yang diperoleh pada tahap pratindakan dijadikan acuan dalam melaksanakan tindakan pada siklus pertama dengan tujuan agar diperoleh suatu peningkatan hasil belajar siswa. Pada penelitian ini setiap siklus terdiri dari empat komponen yaitu perencanaan, pelaksanaan tindakan, observasi, dan refleksi.

Perencanaan dilakukan dengan menyiapkan hal-hal yang dibutuhkan dalam melaksanakan tindakan pada proses pembelajaran Matematika tentang nilai dan ksetaraan pecahan mata uang.

Pelaksanaan tindakan merupakan penerapan rancangan tindakan yang telah disusun berupa pembelajaran matematika dengan menggunakan media video pembelajaran. Penelitian pada siklus I terdiri dari satu pertemuan.

Pengamatan atau Observasi dilaksanakan selama proses pembelajaran berlangsung dengan menggunakan lembar observasi yang telah dibuat sebelumnya.

Tabel 2. Hasil belajar siswa pada Siklus I

\begin{tabular}{|l|l|}
\hline Keterangan & Hasil Belajar siklus I \\
\hline Nilai tertinggi & 100 \\
\hline Nilai terendah & 20 \\
\hline Rata - rata Nilai & 66 \\
\hline Siswa belajar Tuntas & $50 \%$ \\
\hline Siswa belajar Belum Tuntas & $50 \%$ \\
\hline
\end{tabular}


Tabel 3. Perbandingan hasil tes kondisi awal dengan siklus I

\begin{tabular}{|l|l|l|}
\hline Keterangan & Kondisi awal & Hasil Belajar siklus I \\
\hline Nilai tertinggi & 80 & 100 \\
\hline Nilai terendah & 20 & 20 \\
\hline Rata - rata Nilai & 65 & 66 \\
\hline Siswa belajar Tuntas & $30 \%$ & $50 \%$ \\
\hline Siswa belajar Belum Tuntas & $70 \%$ & $50 \%$ \\
\hline
\end{tabular}

Dari hasil analisa data peningkatan hasil belajar kognitif siswa siklus I dapat disimpulkan bahwa persentsi hasil belajar siswa yang tuntas naik dari $30 \%$ kondisi awal menjadi $50 \%$ setelah siklus I, berarti mengalami kenaikan sebesar $20 \%$, dengan nilai batas tuntas < 75. Adapun Nilai tertinggi pada kondisi awal adalah 80 setelah siklus I menjadi 100. Rata-rata nilai pada kondisi awal 65 setelah siklus I menjadi 66. Pada siklus I ternyata masih ada siswa yang belum tuntas belajarnya sehingga guru berusaha untuk mengadakan perbaikan bagi siswa yang belum mencapai batas tuntas, dan memberikan pengayaan kepada siswa yang sudah mencapai kriteria ketuntasan minimal $(\mathrm{KKM}=75)$. Pelaksanaan Perbaikan dan Pengayaan ini dilaksanakan pada siklus II.

Refleksi yang dilakukan pada akhir siklus I bertujuan untuk mengetahui keberhasilan dari pembelajaran yang telah dilakukan. Dalam hal ini peneliti dan mitra peneliti melakukan diskusi untuk mengkaji kembali atau mengevaluasi data dan tindakan yang telah dilakukan pada siklus I sebagai upaya perbaikan pada siklus selanjutnya. Berdasarkan hasil observasi dan hasil tes pada siklus I, indikator keberhasilan belum tercapai. Ada beberapa hal yang harus diperbaiki. Hal ini dimaksudkan untuk memperbaiki pelaksanaan pembelajaran matematika menjelaskan nilai dan kesetaraan pecahan mata uang dengan menggunakan media video pembelajaran agar dapat mencapai indikator keberhasilan yang telah ditentukan.

Deskripsi Penelitian Siklus II

Pada penelitian ini setiap siklus terdiri dari empat komponen yaitu perencanaan, pelaksanaan tindakan, observasi, dan refleksi. Secara rinci sajian siklus 2 adalah sebagai berikut : a. Perencanaan, Perencanaan dilakukan dengan menyiapkan hal-hal yang dibutuhkan dalam melaksanakan tindakan pada proses pembelajaran Matematika, diantaranya: 1) Peneliti dan guru menetapkan waktu pelaksanaan tindakan kelas, 2) Membuat RPP yang didesain sesuai dengan penerapan penggunaan media dalam pembelajaran Matematika, 3) Menyiapkan media pembelajaran yang akan digunakan dalam penelitian, yaitu media video pembelajaran tentang nilai dan kesetraan pecahan mata uang, 4) Menyiapkan metode pembelajaran yang akan digunakan dalam penelitian, 5) Menyiapkan lembar observasi yang digunakan untuk mengamati aktivitas guru dan siswa selama proses pembelajaran, 6) Menyiapkan kamera untuk mendokumentasikan aktivitas guru dan siswa pada proses pembelajaran, 7) Menyiapkan evaluasi hasil belajar siswa yang digunakan pada akhir siklus. b. Pelaksanaan : Pelaksanaan tindakan merupakan penerapan rancangan tindakan yang telah disusun berupa pembelajaran matematika dengan menggunakan media video pembelajaran. Penelitian pada siklus II terdiri dari satu pertemuan. ( Kegiatan Awal, Kegiatan Inti dan Akhir ), c.Pengamatan : Observasi dilakukan oleh peneliti bekerjasama dengan mitra peneliti (teman sejawat). Teman sejawat yang 
bertindak mengamati aktivitas setiap siswa kelas II SDN Dukun 1 selama proses pembelajaran, d. Refleksi : Dari hasil pelaksanaan perbaikan pembelajaran dan refleksi siklus II maka dapat disimpulkan bahwa pelaksanaan tindakan pembelajaran untuk meningkatkan hasil belajar siswa dalam kegiatan pembelajaran Matematika menentukan nilai dan kesetaraan pecahan mata uang dapat diakhiri pada siklus II

Tabel 4. Hasil belajar siswa pada Siklus II

\begin{tabular}{|l|l|}
\hline Keterangan & Hasil Belajar siklus II \\
\hline Nilai tertinggi & 100 \\
\hline Nilai terendah & 60 \\
\hline Rata - rata Nilai & 90 \\
\hline Siswa belajar Tuntas & $90 \%$ \\
\hline Siswa belajar Belum Tuntas & $10 \%$ \\
\hline
\end{tabular}

Tabel 5. Perbandingan hasil tes kondisi awal dengan siklus I dan II

\begin{tabular}{|l|l|l|l|}
\hline Keterangan & Kondisi awal & $\begin{array}{l}\text { Hasil Belajar } \\
\text { siklus I }\end{array}$ & $\begin{array}{l}\text { Hasil Belajar siklus } \\
\text { II }\end{array}$ \\
\hline Nilai tertinggi & 80 & 100 & 100 \\
\hline Nilai terendah & 20 & 20 & 60 \\
\hline Rata - rata Nilai & 65 & 66 & 90 \\
\hline Siswa belajar Tuntas & $30 \%$ & $50 \%$ & $90 \%$ \\
\hline $\begin{array}{l}\text { Siswa belajar belum } \\
\text { Tuntas }\end{array}$ & $70 \%$ & $50 \%$ & $10 \%$ \\
\hline
\end{tabular}

Dari hasil analisa data peningkatan hasil belajar kognitif siswa siklus II dapat disimpulkan bahwa persentsi hasil belajar siswa yang tuntas naik dari $50 \%$ kondisi awal menjadi $90 \%$ setelah siklus 2, berarti mengalami kenaikan sebesar $40 \%$, dengan nilai batas tuntas < 75. Adapun nilai terendah pada siklus I adalah 20 sedangkan setelah siklus II mengalami kenaikan menjadi 60. Nilai tertinggi pada kondisi awal adalah 80 setelah siklus I menjadi 100, serta pada siklus II menjadi 100. Rata-rata nilai pada kondisi awal 65 setelah siklus I menjadi 66 dan pada siklus II menjadi 90 . Hal itu menunjukkan bahwa hasil tindakan perbaikan pembelajaran pada tahap siklus II sudah ada peningkatan lebih besar dibandingkan dengan hasil pembelajaran pada siklus I karena hampir semua siswa nilainya sudah memenuhi KKM, yaitu 75.

\section{SIMPULAN}

Berdasarkan penelitian tindakan kelas yang dilakukan di kelas II SDN Dukun 1 Kecamatan Karangtengah Kabupaten Demak dapat disimpulkan bahwa penggunaan media video pembelajaran dapat meningkatkan hasil belajar Matematika materi nilai dan kesetaraan pecahan mata uang. Peningkatan hasil belajar ditandai dengan nilai siswa yang mencapai KKM sebesar 75 , yakni pada pra siklus nilai 
dari 20 siswa diketahui hanya $6(30 \%)$ siswa yang tuntas. Kemudian pada siklus I meningkat menjadi $10(50 \%)$ siswa yang tuntas. Pada siklus II mengalami peningkatan yaitu sebanyak $18(90 \%)$ siswa tuntas serta adanya peningkatan Kriteria Ketuntasan Klasikal pada siklus I sebesar $50 \%$ dan siklus II sebesar $90 \%$ siswa yang tuntas.

Berdasarkan hasil penelitian yang dilakukan di SDN Dukun 1 Kecamatan Karangtengah, Kabupaten Demak semester I tahun pelajaran 2020/2021, maka peneliti memberikan saran sebagai berikut: 1 . Hendaknya guru lebih kreatif dalam mengemas pembelajaran agar siswa tidak mudah bosan pada saat pembelajaran berlangsung, serta mengikut sertakan siswa dalam proses pembelajaran. 2. Siswa diharapkan untuk lebih aktif dalam mengikuti pembelajaran yang disampaikan oleh guru sehingga hasil belajarnya dapat meningkat.3. Pihak sekolah sebaiknya mengadakan pembinaan terhadap guru untuk melatih guru terutama pembinaan tentang bagaimana guru harus mengemas pembelajaran, karena jika guru berhasil mengemas pembelajaran dengan menarik maka siswa akan lebih tertarik dan lebih memperhatikan pada saat proses pembelajaran.

\section{DAFTAR PUSTAKA}

Arikunto, Suharsimi. 2006. Prosedur Penelitian. Jakarta: Rineka Cipta

Arikunto, Suharsimi., dkk. 2008. Penelitian Tindakan Kelas. Jakarta: Bumi Aksara Arsyad, Azhar. (2011). Media Pembelajaran. Jakarta: Raja Grafindo Persada

Asep Syamsul M. Romli. 2012. Jurnalistik Online: Panduan Mengelola Media Online. Bandung. : Nuansa Cendikia

Darsono, Max, dkk. 2000. Belajar dan Pembelajaran. Semarang: CV.IKIP Semarang Press

DR. Sulipan https://endangkurnia.files.wordpress.com/2010/11/penelitiantindakankelas endang.pdf

Purnomosidi, 2017. Tema 3 Tugasku Sehari-hari Buku Tematik Terpadu Kurikulum 13Buku Siswa SD/MI Kelas II. Jakarta: Kementerian Pendidikan dan Kebudayaan.

Sanjaya, Wina. 2008. Perencanaan dan Desain Sistem Pembelajaran. Jakarta: Kencana Prenada Media Group.

Sudjana, Nana. 2000. Dasar-Dasar Proses Belajar Mengajar. Bandung: PT. Sinar Baru Algensindo 